\author{
Abstracta Iranica \\ Abstracta Iranica Revue bibliographique pour le domaine irano-aryen \\ Volume 42-43 | 2021 \\ Comptes rendus des publications de 2019-2020
}

\title{
Martin Heimgartner. Die Briefe 40 und 41 des Ostsyrischen Patriarchen Timotheos I
}

Florence Jullien

\section{(2) OpenEdition}

Journals

\section{Édition électronique}

URL : https://journals.openedition.org/abstractairanica/51937

DOI : 10.4000/abstractairanica.51937

ISSN : 1961-960X

Éditeur :

CNRS (UMR 7528 Mondes iraniens et indiens), Éditions de l'IFRI

\section{Référence électronique}

Florence Jullien, « Martin Heimgartner. Die Briefe 40 und 41 des Ostsyrischen Patriarchen Timotheos I », Abstracta Iranica [En ligne], Volume 42-43 | 2021, document 4, mis en ligne le 30 décembre 2020, consulté le 05 janvier 2023. URL : http://journals.openedition.org/abstractairanica/51937 ; DOI : https://doi.org/10.4000/abstractairanica.51937

Ce document a été généré automatiquement le 5 janvier 2023.

Tous droits réservés 


\title{
Martin Heimgartner. Die Briefe 40 und 41 des Ostsyrischen Patriarchen Timotheos I
}

\author{
Florence Jullien
}

\section{RÉFÉRENCE}

Martin Heimgartner. Die Briefe 40 und 41 des Ostsyrischen Patriarchen Timotheos I. (Corpus

Scriptorum Christianorum Orientalium 673-674, script. syr. 261-262), Louvain : Peeters

Publishers, 2019, XXXVIII-121 p. ISBN 9789042938670 \& XL-147 p. ISBN 9789042938663

1 Ces 2 volumes (textus et versio) s'inscrivent dans la vaste œuvre entreprise par l'A., l'édition commentée de la correspondance du patriarche de l'Église syro-orientale Mār Timothée $\mathrm{I}^{\mathrm{er}}$ (727/8-823). Il s'agit ici des Lettres 40 et 41 : ces deux pièces restaient jusqu'ici peu accessibles et font l'objet d'une édition désormais référente. Le texte syriaque est accompagné d'une traduction en allemand. Ces documents sont particulièrement importants pour l'historien. La première est le fruit d'une discussion théologique avec un aristotélicien musulman que le patriarche rencontra à la cour califale de Bagdad. Comme le souligne l'A., ce texte est un témoin notable non seulement dans le cadre des confrontations avec l'islam, mais aussi pour l'histoire de la transmission de la logique aristotélicienne au monde arabe. La lettre 41 est adressée aux moines du monastère de Mār Mārōn et apparaît comme l'une des pages les plus complètes sur la pensée théologique du patriarche - un document par ailleurs particulièrement important pour l'histoire des débuts de l'Église maronite. 


\section{AUTEURS}

FLORENCE JULLIEN

CNRS, CeRMI, Paris 